\title{
СОЦИОЛИНГВИСТИЧЕСКИЕ ИССЛЕДОВАНИЯ 21 ВЕКА В РОССИИ: ТЕМАТИКА И ПРОБЛЕМЫ
}

\author{
Надеина Татьяна Михайловна \\ д.филол.н., профессор \\ ФГБОУ ВО «Московский государственный юридический \\ университет имени О.Е. Кутафина (МГЮА)»
}

Аннотация: в статье представлено разнообразие тематики российских научных исследований, посвященных проблемам социолингвистики, которые были опубликованы в 2000-20021 гг. Выявлены наиболее актуальные направления, а также темы, которым уделяется меньшее внимание. Указаны сферы исследований, которые представляют интерес для юридической лингвистики и производства судебных экспертиз.

Ключевые слова: языковая ситуация, языковая политика, социальная стратификация языка, речевой портрет, судебная лингвистика

\section{SOCIOLINGUISTIC STUDIES OF THE $21^{\text {st }}$ CENTURY IN RUSSIA: TOPICS AND PROBLEMS}

\section{Nadeina Tatiana Mikhailovna}

\begin{abstract}
Russian scientific studies on the sociolinguistics problems, which were published in 2000-2001. The most actual areas have been identified, as well as topics that receive less attention. The areas of research that are of interest for legal linguistics and forensic expertise are indicated.

Keywords: language situation, language policy, social stratification of language, speech portrait, forensic linguistics

Цель статьи - обозначить основные направления и тематику социолингвистических исследований отечественных ученых за два десятилетия XXI века и выделить основные их результаты, которые могут быть использованы в практических целях, в частности при решении задач, стоящих
\end{abstract}


перед юридической лингвистикой (forensic linguistics), а также при производстве судебных речеведческих экспертиз.

Поиск и отбор публикаций осуществлялся в научных электронных библиотеках eLIBRARY.ru и КиберЛенинка. Для изучения мы выбирали те источники, в названии или в ключевых словах которых встречалось слово «социолингвистика» и производные от него, а также некоторые исследования из пограничных отраслей лингвистического знания. В общей сложности было проанализировано около 200 научных трудов. Наша выборка не претендует на полноту охвата социолингвистической проблематики, в частности, мы не изучали многочисленные публикации по межкультурной коммуникации, поскольку они достойны отдельного обзорного исследования. Многие работы, возможно, остались без должного внимания, о чем мы искренне сожалеем.

Подводя итог развитию социолингвистики в России XX века, В. Ю. Михальченко в 1999 г. выделила три этапа ее формирования и активной разработки понятийного аппарата:

- первый этап (1920-1930-е годы) - период языкового строительства, для которого были характерны поиски путей функционального развития письменных языков России и создание письменностей для ранее бесписьменных языков;

- второй этап (1970-е годы) - период теоретического осмысления социальной лингвистики; создание и публикация теоретических трудов Ю. Д. Дешериева, В. А. Аврорина, Л. Б. Никольского, А. Д. Швейцера;

- третий этап (80-90-е годы) - период, основным показателем которого является осознание необходимости разработки понятийного аппарата; начало лексикографической работы [1].

К концу XX века в российской социолингвистике сложилось несколько научных школ, восходящих к идеям классиков отечественной лингвистики.

Петербургская школа социолингвистики, возродившаяся в 90-х годах прошлого века на базе исследований, проводившихся в 20-е годы в рамках Петербургской лингвистической школы известными российскими лингвистами Е. Д. Поливановым, А. М. Селищевым, Л. П. Якубинским, В. М. Жирмунским, О. Я. Шор, Б. А. Лариным и др., которые развивали идеи И. А. Бодуэна де Куртене о социальной природе языка, о «горизонтальном» (= территориальном) и «вертикальном» (собственно социальном) членении языка. Центром социолингвистики в Санкт-Петербурге считают Европейский университет, где 
предметом научных исследований являются: социальные варианты языка и языковые регистры, вариационная модель языковых изменений, социолингвистика речевого поведения, билингвизм и переключение кодов, (само)идентификация через язык, языковой сдвиг и креолистика, отношение к языку и этноязыковые стереотипы, языковая ситуация в новых государствах постсоветского пространства [2]. Ряд проблем социолингвистики исследуют также ученые Санкт-Петербургского государственного университета, а также Российского государственного педагогического университета им. А. И. Герцена.

\section{Московская школа функциональной социолингвистики связана с} именами М. В. Панова, Л. П. Крысина, Д. Н. Шмелева, Е. А. Земской и др., изучавших функциональную сторону русского языка, его коммуникативные и прагматические свойства. Предметами изучения являются: взаимодействие языков и языковых подсистем; языковая социализация личности; кодовые переключения; создание социально-речевых портретов [3].

Пермская школа социолингвистики, возникшая в начале $70-\mathrm{x}$ гг. XX века, базируется на идеях петербургских ученых Л. В. Щербы, Б. А. Ларина, СЛ. С. Ковтун, Л. А. Вербицкой и др. Основной областью научных исследований этой школы в конце ХХ века являются социальная диалектология и лингвистическая конфликтология. Исследование пермского региолекта вызвало необходимость изучения языковой ситуации в регионе особенностей русской речи коренного населения Пермского края, комипермяков и татар, т.е. билингвов [4]; [5].

Выделяется также Уфимская школа социолингвистики и психолингвистики, развивающая идеи Московской и Пермской школ. Представители этой школы изучают социальную и коммуникативную базу языков в крупных полиэтнических районах (Краснокамском и Зауралье) [6].

Во втором десятилетии XXI века было опубликовано несколько обзоров, посвященных основным направлениям современной российской социолингвистики в настоящее время: [7]; [8]; [9]; [10]; [11]; [12]. Авторы отмечают междисциплинарный характер социолингвистики как отрасли научного знания, указывают на ее связь с социологией, социальной психологией, этнографией, культурологией.

Примечательно, что мнения авторов о наиболее важных, актуальных проблемах современной социолингвистики не вполне совпадают. 
Первостепенное значение они придают разным направлениям исследований в этой области, что объясняется, по-видимому, сферой их научных интересов.

Так, М. Д. Сеттарова наиболее актуальной считает проблему социальной дифференциации языка, далее следуют проблемы взаимодействия языка и нации, языка и культуры, проблема социальных аспектов билингвизма, проблема языковой политики [7].

И.В. Щеглова позиционирует социолингвистику как науку, изучающую особенности функционирования национальных языков, поскольку другие проблемы, традиционно включаемые в ее предметную область, «стали объектом изучения самостоятельных лингвистических направлений или наук, таких как гендерная лингвистика, возрастная лингвистика, теория межкультурной коммуникации, лингвокоммуникативистика, лингвоперсонология, лингвокультурология» [8, с. 138]. Перспективными направлениями исследований автор считает осмысление, углубленное изучение таких ключевых понятий, как языковая ситуация, языковое состояние, би(поли)лингвизм, естественный билингвизм, языковая политика. Такие выводы сделаны на основании анализа научных исследований российских школ социолингвистики, а также содержания диссертационных исследований, защищенных в период с сентября 2015 года по август 2016 года и посвященных изучению проблем функционирования национальных языков народов, проживающих на территории РФ, предметом которых является национальнорусское двуязычие, взаимодействие контактирующих языков и витальность национальных языков. Всего было найдено 11 источников. На основании этого И. В. Щеглова сделала вывод о том, что «отечественная социолингвистика переживает не лучшие времена» [8, с. 138].

В 2018 году опубликован еще один обзор, посвященный актуальным направлениям развития современной социолингвистики [9]. Важнейшей проблемой А.Д. Васильев и С.П. Васильева называют проблему социальной дифференциации языка в аспекте эффективности коммуникации между представителями разных слоев общества, в плане взаимного понимания коммуникантов [9, с. 154]. Конкретизируя указанную проблему, авторы поясняют, что актуальными в настоящее время являются исследования в области массового словоупотребления, в частности строящиеся по модели ассоциативного эксперимента, поскольку их результаты позволяют в должной мере объективно установить состояние и главные векторы общественного сознания [9, с. 156]. В соответствии с этим актуальными направлениями 
развития современной социолингвистики, по мнению авторов, являются политическая лингвистика и психолингвистика: 1) задача современных социолингвистических исследований заключается в выявлении фактов эволюции языковых единиц, главным образом лексем, приводящих к вариативности понимания, на основе которой, в частности в политическом дискурсе, строятся коммуникативные стратегии и тактики манипулятивного воздействия на общественное сознание; 2) достоверными способами определения духовно-нравственного состояния этноса являются экспериментальные исследования и описание результатов массового ассоциативного эксперимента, демонстрирующего наиболее объективированные данные о шкале этнокультурных ценностей современного [9, с. 157].

Н. Н. Германова в части 1 учебного пособия «Актуальные направления современного языкознания» [10] подчеркнула связь социолингвистики с социальной психологией языка, лингвопрагматикой, когнитивной лингвистикой и критической лингвистикой (критическим анализом дискурса) [13]. В книге сделан акцент на социальную дифференциацию языка и гендерное варьирование. Отмечено, что результаты гендерных исследований представляют практический интерес для идентификационной диагностики, определяющей личностные характеристики анонимных авторов с опорой на письменные и устные тексты, что имеет непосредственное отношение к судебно-экспертной деятельности.

В обзорах Я. В. Евсеевой к основной проблематике отечественных работ, включая магистерские и кандидатские диссертации, относятся этноязыковые стереотипы и идентификация через язык, соотношение языка и идеологии, языковая ситуация в постсоветских государствах, языковой сдвиг и креолистика, билингвизм и переключение кодов, социальные варианты языка и вариационная модель языковых изменений, социолингвистика речевого поведения [11].

Важным событием нынешнего века является появление журнала «Социолингвистика» - первого отечественного социолингвистического журнала, издаваемого Институтом языкознания РАН (Москва) и Орловским государственным университетом им. И.С. Тургенева при участии Ассоциации российских социолингвистов. По мнению членов редколлегии, на современном этапе в фокусе внимания находятся такие задачи, как развитие и переосмысление ключевых социолингвистических понятий (родной и 
государственный язык, языковая политика и междисциплинарных подходов для анализа социальных практик, идеологий и установок, лежащих в основе выбора языка/языков. Первый номер освещает следующие вопросы: социолингвистика в ряду других дисциплин, языковое планирование, полевые исследования функционирования языков народов РФ. Я.В. Евсеева отмечает, что, не будучи тематическим, номер в значительной мере посвящен государственной политике в отношении языков Российской Федерации, что свидетельствует об интересе отечественных социолингвистов к данной теме [12].

Далее представлены результаты проведенного нами исследования, которые распределены по темам, отражающим основные проблемы социолингвистики.

\section{Язык и общество}

В данной теме мы сделали акцент на взаимосвязи языка и общества, рассматриваемой в аспекте изменений, которые происходят в языке вследствие появления новых общественно-политических реалий.

Ряд актуальных проблем состояния и функционирования русского языка в условиях глобальный культурных и социально-экономических изменений: употребление русского языка в современной массовой и межличностной коммуникации, основные факторы, определяющие состояние языка охарактеризованы в статье [14].

Проблеме влияния глобализации на языковые процессы посвящена коллективная монография [15]. В ней опубликованы результаты поэтапной реализации международной научной программы по изучению феноменов «язык - культура - этнос» (предшествующие публикации по названной программе: Язык - культура - этнос. М.: "Наука", 1994; Язык как средство трансляции культуры. М.: "Наука", 2000; Встречи этнических культур в зеркале языка. М.: "Наука", 2002). Работа над программой осуществлялась на основе двустороннего международного сотрудничества Института славяноведения РАН и Института чешского языка Чешской АН.

Последствия процесса глобализации являются предметом изучения в работах: [16]; [17]; [18]; [19]; [20]; [21]; [22]; [23]; [24].

Изменения лингвистического облика городов (вывески, объявления, надписи и т.п.) в связи с либерализацией законодательства вызвали появление теории лингвистического ландшафта, этой теме посвящены работы [25]; [26]. 
В статье [27] изучение языковых ландшафтов наряду с другими социолингвистическими методами предлагается использовать для исследования русского языка за рубежом.

\section{Языковая ситуация}

Теоретическому осмыслению понятия «языковая ситуация» посвящены работы [28]; [29]; [30]; [31]; [32]; [33]; [34]; [35].

Языковая ситуация в полиэтническом обществе рассматривается как в теоретическом аспекте [36], так и на конкретном региональном материале: в Пермском крае [37]; [38], в городе Уфе [39], в Кировской области (речевое поведение российских немцев) [40], в Мурманской области [41]; в Республике Крым [42]; в Республике Саха (Якутия) [43]. Функционированию крымскотатарского языка в Республике Крым посвящена статья [44].

Языковые и этнические конфликты на постсоветском пространстве в интернет-коммуникации являются предметом изучения в [45].

Довольно много работ посвящено исследованию языковой ситуации в зарубежных странах, среди которых в качестве примера упомянем одну, посвященную экспериментальному исследованию языковой ситуации в китайской диаспоре Австралии [46].

Непосредственно связаны с языковой ситуацией проблемы языковых контактов. В рамках этой темы можно выделить работы, посвященные языковому разнообразию и витальности языков: [47]; [48].

В работе [49] изложены итоги проекта по разработке информационной системы «Языковое разнообразие России».

Вопрос многоязычия рассматривается в теоретическом аспекте в работе [50]; теоретическим и методологическим основам изучения полиэтнолекта посвящена статья [51].

Исламский вариант русского языка рассмотрен в работе [52].

В работе [53] охарактеризованы лексические особенности русской речи коми-пермяков.

Проблемы билингвизма и диглоссии обсуждаются в работах [54]; [55]; интерференции на уровне интонации посвящена статья [56]; переключение кодов является предметом исследований [57]; [58].

Проблемам транслингвальных и транскультурных контактов посвящен специальный выпуск журнала «Социальные и гуманитарные науки на Дальнем Востоке» [59]. В нем преобладают статьи, освещающие эти вопросы на 
материале не национальных языков РФ, а китайского английского, японского английского языков, английской речи носителей языков Восточной Азии в целом [6, с. 140].

Много внимания уделяется разновидностям иностранных языков, наиболее популярной темой здесь является спанглиш - американизированный испанский язык. Статус этой разновидности языка обсуждается в работах [60]; [61]; [62]. Разновидность спанглиша - киберспанглиш (англицизмы в киберпространстве испанского языка) рассматривается в работе [63].

На материале немецкого языка в статье [64] раскрываются понятия этнолект и мультиэтнолект как продукты взаимодействия языковых систем. В работе [65] охарактеризованы социальные функции вариантов сербохорватского языка.

\section{Языковая политика}

Эта тема является весьма популярной в ряду рассмотренных нами публикаций, что объясняется ее чрезвычайной актуальностью в связи со сложившейся в последние годы международной и внутренней общественнополитической обстановкой.

Проводятся конференции, круглые столы, посвященные языковой политике и связанными с ней проблемами, материалы которых представлены в сборниках конференций и на страницах журнала «Социолингвистика» [66]; [67]; [68].

Проблемам объема и содержания понятий «языковая политика» и «языковое планирование», рассматриваемых в лингвистическом аспекте, посвящены работы [69]; [70]; [71]. Разные типы языковой политики рассмотрены в [72].

Подходы к изучению языковой политики и языковому планированию предлагаются в статьях [73]; [74].

Ряд работ посвящен анализу языковой политики в Российской Федерации: [75]; [76]; [77]. Сценарии в языковой политике России рассмотрены в работе [78]. Языковая политика в республиках постсоветской России охарактеризована в статье [79]. Работа [80] посвящена языковой политике в российско-скандинавском приграничье.

Украинская языковая политика охарактеризована в работе [81].

Языковая политика в сфере образования на территориях проживания коренных малочисленных народов Севера в Красноярском крае 
охарактеризована в [82]. В статье [83] сделаны выводы о состоянии и перспективах изучения украинского языка в российских школах.

Эффектам языковой политики в экономической сфере посвящены работы [84]; [85].

Правовому и функциональному статусу языков РФ посвящена статья [86].

Опыт сохранения исчезающих языков изложен в статье [87], где описана современная методика, успешно использованная в штате Калифорния, США.

Вопросы миграционной политики освещает статья [88].

\section{Коммуникативная ситуация}

Коммуникативная ситуация как одно из центральных понятий при описании социально-коммуникативной системы в исследованиях из нашей выборки представлена в минимальной степени.

Статья [89] посвящена одному из компонентов коммуникативной ситуации - тональности. В работе [90] коммуникация в языковом коллективе рассматривается как элемент социальных отношений. Статья [91] освещает психологический аспект коммуникации и содержит результаты исследования лингвистической идентичности и потребности в языке. В работе [92] теория речевых актов рассмотрена с точки зрения лингвистической антропологии и социолингвистики. Исследованию коммуникативной практики жителей города (как самостоятельной коммуникативной системы, а также системы семиотических знаков, сопровождающих индивидуума) посвящена работа [93].

\section{Социальная стратификация языка}

Теоретико-методологические подходы к социальной стратификации разных форм существования языка предложены в работах [94]; [95].

Популярной темой является социальная диалектология, или социолектология, а также социолекты. Обзор современного состояния и проблем социолектологии, которая позиционируется как раздел социолингвистики, представлен в работе [96]. Основам контрастивной социолектологии посвящена работа [97], ее категориально-понятийная система раскрыта в статье [98]. Основные направления исследований в области социальной диалектологии, проводимые в Пермском университете, охарактеризованы в работе [99]. 
Изучаются также и различные лингвистические характеристики социолектов. Работа [100] посвящена функциональной семантике универбов в русских социолектах.

Важным аспектом этой темы является социолектография, которая изучает принципы составления словарей со стилистически и социально маркированными лексемами. Процесс формирования русской социолектной лексикографии как самостоятельной отрасли языкознания и ее современное состояние охарактеризованы в работе [101].

В статье [102] дается обзор проблематики лексикографической обработки соцолектного материала и предлагается типология словарей по их величине и способам описания жаргонизмов, сленгизмов и арготизмов. Принципы составления двуязычного словаря профессионального языка изложены в [103].

\section{Формы существования общенародного русского языка}

Территориальным диалектам русского языка, изучаемым в социолингвистическом аспекте, посвящены исследования в области диалектологии, акцент в которых сделан на описании языковой личности носителя диалекта и его речевого портрета: галерея речевых портретов сельских жителей Русского Севера [104]; языковая личность жительницы русского Севера [105]; речевой портрет жительницы Северного Приангарья [106]; региональная идентичность жителей Вологодского края [Ильина 107]; речевой портрет жителя Вологодского края [108]; фрагмент речевого портрета жителя современного российского села [109]; фонетические и морфологические черты речевого портрета носителя диалекта [110]; гендерный аспект диалектной речи [111].

Социолингвистические подходы к исследованию приграничного северного региона охарактеризованы в работе [112].

В качестве эмпирической базы для дальнейших исследований диалектной языковой личности создан мультимедийный корпус «Жизненный круг» [113].

Предметом изучения становится также и языковое сознание носителей диалекта. Так, в работе [114] показано, как в области наивного знания рядовых говорящих отражаются представления о многообразии социокультурных вариантов языка и их соотношении (нормированность/ненормированность, письменная/устная форма бытования, социальная дифференциация и др.).

Просторечие как специфичная форма существования русского языка в традиционном понимании (в трактовке Л.П. Крысина) является одной из 
активно обсуждаемых проблем социолингвистики. Исторический аспект этого явления раскрыт в статье [115].

В ряду обсуждаемых проблем находится неоднозначность понятия «просторечие» в русском языке [116], [117]; стилистический статус просторечия [118], [119] и неоднородность состава [120]; его функциональносемантическая специфика [121].

В качестве одной из разновидностей просторечия в работе [122] выделяется профессиональное просторечие как язык для специальных целей (на наш взгляд, примыкающее скорее к профессиональным жаргонам).

Проблемным вопросом является также лексикографическое описание просторечия [123]. Причина заключается в трудностях разграничения просторечной и разговорной лексики в русском языке [124]; [125]; [126].

В работе [127] предпринят обзор словарей, отражающих различные социально-стилистические пласты лексики, которым автор дал обобщающие название «просторечие». Строго говоря, эти словари относятся к сфере социолектографии, о которой уже шла речь выше.

Ряд работ посвящен просторечным признакам, проявляющимся в речи жителей: г. Тамбова [128]; [129]; Приамурья [130]; г. Омска [131]. Особенности идиолексикона носителя городского просторечия охарактеризованы в работах [132]; [133].

В статье [134] рассмотрены модификации, которые происходят со специальной терминологией (медицинской, технической и др.) в речи носителей городского просторечия.

Популярной разновидностью общенародного русского языка становится разговорно-обиходная речь, которая в отдельных элементах пересекается с традиционным просторечием. В работах [135]; [136] охарактеризованы ее лексические особенности и предложены принципы лексикографического описания. Проблемам и перспективам лексикографии разговорной (субстандартной) лексики посвящены работы [137]; [138].

Опубликован «Толковый словарь русской разговорно-обиходной речи» [139]. Статья [140] представляет собой рецензию на эту книгу. Достоинство словаря, по мнению рецензента, заключается в том, что в нем единицы разговорно-обиходной речи представлены в диктуемых языковым обиходом обстоятельствами, что важно для производства лингвистических экспертиз спорных текстов. 
Статья [141] содержит результаты пилотного исследования особенностей русского языка повседневного общения разных социальных групп современного российского города. Получены количественные данные об особенностях каждой группы на фонетическом, лексическом, морфологическом и синтаксическом уровнях. Другой аспект этой работы касается анализа функционирования прагматем разного типа в устной спонтанной речи представителей разных социолектов и проверки диагностических возможностей данного лингвистического параметра для установления специфики того или иного социолекта [142].

В Институте русского языка им. В.В. Виноградова РАН ведется работа по составлению «Толкового словаря русской разговорной речи». В статье [143] раскрыты принципы составления этого словаря и его содержание. Опубликован первый выпуск [144]. В статье [145] на материале словарных статей из этого словаря анализируется речевая манера советских и современных политиков.

В работе [146] изложены результаты социолингвистического эксперимента, в котором изучалось использование слов-паразитов в русской разговорной речи.

Проблемы определения и разграничения понятий «жаргон», «арго», «сленг» остаются предметом обсуждения в современных исследованиях. В статье [147] охарактеризован лингвистический подход к понятию «жаргон». Результаты анализа дефиниций указанных терминов, содержащихся в словарях, изложены в [148], предложена дефиниция понятия «субстандарт». В работе [149] раскрывается понятие «профессиональное арго» и формулируются задачи современной аргологии.

Проблемам лексикографической фиксации жаргонов посвящены статьи [150]; [151]; [152]. Опыт лексикографирования студенческого жаргона изложен в работе [153]. Статья [154] посвящена специфике отбора эмпирического материала для проведения полипарадигмального анализа французского общего молодежного арго; в ней представлены результаты подготовительной работы по созданию артологических карт.

Неизменный интерес проявляют исследователи к молодежным жаргонам. Изучаются разные их аспекты: особенности функционирования [155], [156]; стилистическая маркированность лексики [157]; модели словообразования [158]; действие социально-демографических факторов, влияющих на употребление [159]; [160]; гендерные различия [161]; характер заимствований [162]; географическая вариативность [163]. 


\section{Социальная маркированность языковых единиц}

Тема социальной маркированности языковых единиц является, на наш взгляд, центральной в социолингвистических исследованиях, поскольку в ее рамках должен осуществляться поиск социолингвистических переменных, т.е. языковых (речевых) единиц или средств, которые с достаточной степенью надежности могут являться индикаторами социальной принадлежности индивида.

В этом направлении ведутся разноплановые исследования, касающиеся соотношения между разными социальными факторами, с одной стороны, и языковыми единицами разных уровней, с другой. Например, такое словообразовательное явление, как универбация, может рассматриваться в качестве маркера социальной стратификации [164].

Влияние возраста и гендера (как важных социально-демографических показателей) на особенности языка и речи индивида является традиционной темой лингвистических исследований. В социолингвистическом аспекте это явление рассматривается в ряде работ, однако, как правило, на материале иностранных языков. Так, в работах [165]; [166] выявлена корреляция между возрастными и ритмотемпоральными характеристиками жителей США. Связь между идиоматикой в повседневной русской речи и гендерными и возрастными показателями охарактеризована в работе [167].

В некоторых работах определены социолингвистические переменные, которые, по мнению авторов, являются социальными индикаторами (маркерами). К числу таких переменных относятся, например: диапазон речи [168] и темп речи (американский вариант английского язык) [169]; интонационные характеристики (афроамериканский диалект в США) [170]; интонационное оформление (английский язык) [171]; ударение и ритм (английский язык) [172]; просодическая организация высказываний (английский язык) [173].

В некоторых работах исследуется связь между профессиональной принадлежностью человека и характеристиками его речи, например, просодия дикторской речи (дикторов американских новостных каналов) [174]. В работе [175] на основе анализа монологических высказываний американских актеров и политиков, реализованных в неформальном общении (интервью), выявлены различия в просодическом оформлении, которые автор считает маркерами профессиональной принадлежности говорящего. 
На материале русского языка связь между языковыми средствами и статусными характеристиками раскрывается в работе [176].

Ряд работ посвящен изучению связи между видом дискурса и специфичными для него языковыми средствами. В центре внимания находятся политический и президентский дискурс. Особенности политического дискурса охарактеризованы в работах [177]; [178]; [179]; принципы изучения политического дискурса в уральской школе политической лингвистики изложены в работе [180]. Исследованию президентского дискурса посвящены работы [181]; [182]; языковые маркеры женского политического дискурса (на примере А. Меркель) охарактеризованы в [181]. Эти исследования находятся в русле одного из междисциплинарных направлений лингвистики лингвоперсонологии, в том числе политической [177], объектом изучения которой является языковая личность.

\section{Речевой портрет}

Речевой портрет как воплощенная в речи языковая личность изучается в рамках разных научных парадигм. Для судебного речеведения эта тема является важной, поскольку методология и результаты исследований в этой области могут быть полезны при решении идентификационных и диагностических задач.

Сущность понятий «речевой портрет» и «языковая личность», а также принципы их изучения раскрыты в работах [184]; [185]; [186]; [187]; методическим основам лингвополитической персонологии и методикам анализа посвящена статья [188]; фонетические характеристики речевого портрета личности рассматриваются в работе [189]; социокоммуникативные установки русской языковой личности охарактеризованы в статье [190].

Неизменно популярным объектом исследований в этой области остаются политические лидеры. Речевой портрет Б.Н. Ельцина охарактеризован в работе [191], дискурсивный портрет В.В. Путина представлен в [192].

Собирательные характеристики языковой личности, принадлежащей какой-либо социальной группе, описаны в работах [193] (личность российского военнослужащего); [194] (сетевая языковая личность). Статья [195] содержит описание речевого портрета носителя просторечия.

Подводя итог нашего краткого обзора российских исследований в области социолингвистики, можно сказать, что ее предметная область 
подверглась заметной диверсификации по сравнению с предыдущим историческим периодом и стала в большей степени междисциплинарной.

Эта отрасль науки за два десятилетия нынешнего века активно развивается, однако это развитие является неравномерным с точки зрения внимания, уделяемого исследователями тем или иным ее проблемам. Прежде всего, это касается такого направления, как социолингвистика речевого поведения, к проблематике которой относится изучение компонентов коммуникативной ситуации, рассматриваемой комплексно, в двух аспектах социальном (с учетом социальных ролей) и ситуативном (с учетом характера ситуации). В области социофонетики недостаточно внимания уделяется проблемам социальной маркированности сегментных и суперсегментных единиц русского языка. И, наконец, практически отсутствуют исследования, направленные не просто на выявление социолингвистических переменных, а на доказательство их релевантности как маркеров социального статуса человека.

\section{Список литературы}

1. Михальченко В. Ю. Российская социальная лингвистика: прошлое, настоящее, будущее // Вопросы филологии. - 1999. - № 2. - С. 27-34.

2. Гулида В. Б., Вахтин Н. Б. Петербургская социолингвистика: пятнадцать лет развития // Вопросы языкознания. - 2010. - № 2. - С. 106-119.

3. Крысин Л.П. Культура речи и функциональная социолингвистика // Вопросы культуры речи: сб. ст. - М., 2012. - С. 38-44.

4. Доценко Т. И., Ерофеева Е. В., Ерофеева Т. И. Пермская школа социолингвистики: теоретические и методологические основания // Вестник Пермского университета. Российская и зарубежная филология. - 2010. - Вып.2 (8). - C.144-155.

5. Ерофеева Т. И. Пермская школа социолингвистики: векторы научных исследований // Социо- и психолингвистические исследования. - 2017. - Вып. 5. - С. 7-18.

6. Щеглова И. В. Российская социолингвистика сегодня // Вестник Северного (Арктического) федерального университета. Серия: Гуманитарные и социальные наука. - 2017. - № 5. - С.138-144.

7. Сеттарова М. Д. Актуальные проблемы социолингвистики // Проблемы современной науки и образования. - 2016. - № 8 (50). - С.101-103. 
8. Щеглова И. В. Российская социолингвистика сегодня // Вестник Северного (Арктического) федерального университета. Серия: Гуманитарные и социальные наука. - 2017. - № 5. - С.138-144.

9. Васильев А. Д., Васильева С. П. Актуальные направления развития современной социолингвистики // Вестник Красноярского государственного педагогического университета им. В.П. Астафьева. Филология. Языкознание. 2018. - C.153-160.

10. Германова Н. Н. Актуальные направления современного языкознания: социолингвистика: Учебное пособие. - М.: МГЛУ, 2018. - 97 с.

11. Евсеева Я. В. Исследования языка в социолингвистике и других социальных науках: проблемы и перспективы: Введение к тематическому разделу // Социальные и гуманитарные науки. Отечественная и зарубежная литература. Сер. 11. Социология. Реферативный журнал. - 2021. - № 1. C. 9-19.

12. Евсеева Я. В. Актуальные вопросы социолингвистики: на материале социолингвистических журналов // Социальные и гуманитарные науки. Отечественная и зарубежная литература. Сер. 11. Социология. Реферативный журнал. - 2021. - № 1. - С.20-45.

13. Трошина Н. Н. Рец. на книгу: Германова Н. Н. Актуальные направления современного языкознания: социолингвистика. - М.: МГЛУ, 2018. Ч. 1: Социолингвистика как раздел языкознания. Проблемы варьирования языка. - 98 с. // Социальные и гуманитарные науки. Отечественная и зарубежная литература. Сер. 6. Языкознание: Реферативный журнал. - 2019. № 3. - С.63-65.

14. Новиков А. Л., Рыбаков М. А. Функционирование русского языка: основные тенденции и их причины // Вестник РУДН, серия Вопросы образования: языки и специальность. -2011 . - № 4. - С.47-54.

15. Глобализация - этнизация: этнокультурные и этноязыковые процессы / отв. ред. Г. П. Немищенко. В 2-х кн. - М., 2006. - Кн. 1. - 486 с. Кн. 2. $-261 \mathrm{c}$.

16. Лапынина Н. Н. О некоторых тенденциях развития словарного состава современного русского языка под влиянием процесса глобализации // Научный вестник Воронежского гос. архитектурно-строительного ун-та. Серия: Лингвистика и межкультурная коммуникация. - 2007. - № 3 (3). - С. 7-14. 
17. Гриценко Е. С., Кирилина А. В. Язык и глобализация: задачи и направления социолингвистического анализа // Вестник Минского гос. лингвистического ун-та. Сер.: Филология. - 2010. - № 6. - С. 14-21.

18. Гриценко Е. С., Кирилина А.В. «Язык и глобализация» в контексте лингвистического образования (конструктивистский подход) // Высшее образование в России. - 2011. - № 3. - С.69-75.

19. Кирилина А. В., Гриценко Е. С. Основные модели описания языковых изменений в условиях глобализации // Власть. Языкознание. - 2011. № 5. - С. 56-59.

20. Балыхина Т. М. Судьба русского языка в условиях американизации высшего образования: прогнозы и факты // Полилингвальность и транскультурные практики. - 2011. - № 4. - С. 5-12.

21. Марусенко М. А. Глобализация и национальные языки // Вестник Московского университета. Серия 22. Теория перевода. - 2013. - № 4. - С. 3-25.

22. Косырева М. С. Особенности развития русского языка в эпоху глобализации // Казачество. - 2017. - № 28. - С. 59-67.

23. Клоков В. Т. Языковые аспекты экономической глобализации // Известия Саратовского университета. Новая серия. Серия Филология. Журналистика. - 2018. - Т.18, вып. 2. - С.138-140.

24. Абдусаламов М. М. Особенности эволюции прагматических контекстов социолингвистики в расширяющемся круге worldenglishes по модели Б. Карчу // Вестник Дагестанского гос. ун-та. Серия 2: Гуманитарные науки. - 2019. - Том.34. - Вып. 1. - С. 62-69.

25. Купцова Г. Контакт языков в лингвистическом ландшафте Москвы (на материале текстов, нанесенных на детские игрушки) // Вопросы психолингвистики. - 2013. - С.204-207.

26. Протасова Е. Ю. Вариативность лингвистического ландшафта России // Экология языка и коммуникативная практика. - 2015. - № 1. C. 91-102.

27. Павленко А. Языковые ландшафты и другие социолингвистические методы исследования русского языка за рубежом // Russian Journal of Linguistics. Вестник РУДН. Серия: Лингвистика. - 2017. - Т. 21. - № 3. C. 493-514.

28. Огдонова Ц. Ц. Социолингвистическая и лингвокультурологическая парадигмы интерпретации концепта «языковая ситуация» // Вестник Забайкальского гос. ун-та (ЧитГУ). - 2009. - № 3 (54). - С. 166-171. 
29. Цыбденова Б. Ж. К вопросу о языковой ситуации // Вестник Бурятского государственного университета. Философия. - 2010. - С. 219-222.

30. Огдонова Ц.Ц. Парадигмальный подход к изучению языковой ситуации // Russian Journal of Linguistics. Вестник РУДН, серия Лингвистика. 2010. - № 3. - C.69-76.

31. Ромашкевич В. Р. Теоретический плюрализм в истолковании понятия «языковая ситуация»// Научный диалог. - 2015. - № 6 (42). C. $107-120$.

32. Аюпова Л. Л., Ромашкевич В. Р. Исследование языковой ситуации: научное осмысление проблемы // Вестник Башкирского университета. - 2015. T. 20. - № 3. - С. 1006-1010.

33. Суюнбаева А. Ж. Языковая ситуация как фактор функционирования языка для специальных целей // Научный диалог. - 2016. - Выпуск № 5 (53). C. 97-108.

34. Щеглова И. В. Языковая ситуация: определение понятия, пути изучения // Филологические науки. Вопросы теории и практики. - Тамбов: Грамота, 2017. - № 8 (74). - Ч. 1. - С. 172-175.

35. Чурилова И. Н., Федорова М.А. История и содержание понятия «Языковая ситуация» // Филологические науки. Вопросы теории и практики. Тамбов: Грамота, 2017. - № 7 (73). - Ч. 2. - С. 192-194.

36. Шхумишкова А. Р. Языковая ситуация и языковая политика в современном поликультурном обществе // Вестник Адыгейского государственного университета. Серия 2: Филология и искусствоведение. 2014. - Выпуск 2 (140). - С. 122-126.

37. Ерофеева Е.В. Языковая ситуация современного города и методы ее исследования // Вестник Пермского университета. Российская и зарубежная филология. - 2009. - Вып. 5. - С.16-23.

38. Ерофеева Е. В. Языковая ситуация Пермского края: особенности русской спонтанной речи и методы исследования // Вестник Пермского университета. Российская и зарубежная филология. - 2013. - Вып.3 (23). C. 7-16.

39. Исмагилова Н. В. Языковая ситуация в мультинациональном городе (на примере города Уфы). // Филологические науки. Вопросы теории и практики. - Тамбов: Грамота, 2018. - № 12 (90). - Ч. 1. - С. 116-122.

40. Байкова О. В., Байкова А. В. Языковая ситуация как один их детерминирующих факторов речевого поведения этнических групп в 
иноязычной среде (на примере российских немцев Кировской области) // Вестник Вятского гос. ун-та. - 2012. - С. 32-35.

41. Бурцева А. В., Рыжкова И. В. Языковая ситуация в Мурманской области: актуальные проблемы // Известия Волгоградского государственного педагогического университета. - 2011. - С. 70-74.

42. Дорофеев В. Ю. О функционировании языков в Республике Крым (на основе социолингвистического исследования) [Электронный ресурс] // Социолингвистика. - 2020. - № 1. - С. 79-93.

43. Иванова Н. И. Языковая ситуация в Республике Саха (Якутия) в фокусе проспективной социолингвистики [Электронный ресурс] // Социолингвистика. - 2020. - № 1. - С. 94-108.

44. Селендили Л. С. К вопросу о функционировании крымскотатарского языка в Республике Крым [Электронный ресурс]. Социолингвистика. - 2020. - № 2 (2). - С. 108-123.

45. Баязитова Р. Ф. Отражение языковых и этнических конфликтов на постсоветском пространстве в интернет-коммуникации: функционирование и типология [Электронный ресурс] // Социолингвистика. - 2021. - № 2(6). C. $145-163$.

46. Денисова В. Л. Языковая ситуация в китайской диаспоре Австралии на основе данных социолингвистического эксперимента // Вестник Челябинского государственного университета. - 2012. - № 13 (267). Филология. Искусствоведение. - Вып. 65. - С.41-43.

47. Ведерникова Е. М. Теория этнолингвистической витальности: Эволюция и современное состояние // Социс. - М., 2014. - № 10 (366). C. 91-96.

48. Башиева С. К., Шогенова М. Ч. Основные факторы витальности республиканских государственных языков (на материале кабардинского и балкарского языков) // Вестник Томского государственного университета. Филология. - 2018. - № 53. - С. 15-31.

49. Горячева М. А., Горячев Н. С. Информационная система «Языковое разнообразие России»: основные итоги проекта // Филологические науки. Вопросы теории и практики. - 2016. - № 11 (65). - Ч. 1. - С. 110-112.

50. Федотова К. А. К вопросу о многоязычии в социолингвистическом и психологическом аспектах // Наука и образование сегодня. - 2019. - С. 50-51. 
51. Велибекова И. М. Теоретические и методологические основы изучения полиэтнолекта // Филологические науки. Вопросы теории и практики. - Тамбов: Грамота, 2016. - № 6 (60). - Ч.1. - С. 85-88.

52. Тарасова Ф. Х., Мухамеджанова Э. Р. Изучение исламского (русского) социолекта в социолингвистике // Современный мусульманский мир. Международный научный журнал Российского исламского института. - 2017.

53. Ерофеева Е. В., Ерофеева Т. И. Русская речь коми-пермяков: лексический аспект // Вестник Пермского университета. Российская и зарубежная филология. - 2017. - Том 9. - Выпуск 4. - С. 48-58.

54. Коровушкин В. П. Билингвизм и диглоссия как проявление социально-языковой ситуации // Вестник Череповецкого гос. университета. 2012. - № 2. - T.2. - С. 97-102.

55. Харитонова Е. В. Диглоссия как особый вариант билингвизма: полисоциолектность русского языка // Вестник РУДН, серия Вопросы образования: языки и специальность. - 2015. - № 5. - С.247-254.

56. Николаев А. И., Артемьев И. Т. Интерференция на уровне интонации в коммуникативных типах предложения в ситуации искусственного многоязычия // Вестник СВФУ. - 2011. - Том. 8. - № 4. С.111-118.

57. Найман Е. А. Языковой кроссинг как форма полиязычного коммуникативного поведения // Язык и культура. - 2017. - С.237-250.

58. Ашрапова А. Х. Теоретические аспекты языковых контактов (на примере переключения кодов) // Современный мусульманский мир. Международный научный журнал Российского исламского института. - 2018. № 1.6 c. [Электронный ресурс] URL: www.islamjournal.ru.

59. Социальные и гуманитарные науки на Дальнем Востоке». - 2016. № 2 (50). $-180 \mathrm{c}$.

60. Масляков В. С. «Спанглиш» как явление языковой мужкультурной коммуникации // Язык и культура. - 2011. - С.51-61.

61. Кудряшова С. В. Социолингвистический статус языкового явления спанглиш // Международный научно-исследовательский журнал. - 2014. C.111-112.

62. Питолин Д. В. Спанглиш как явление языковой межкультурной коммуникации // Педагогическое образование в России. - 2014. - № 6. C.55-58. 
63. Яковлева С. А. Киберспанглиш: обзор терминологической дискуссии // Полилингвальность и транскультурные практики. - 2010. C. 26-31.

64. Акулова М. Е. Этнолект и мультиэтнолект как продукты взаимодействия языковых систем (на примере немецкого языка) // Символ науки. - 2016. - № 4. - С. 177-179.

65. Егорова М. А. О социальных функциях вариантов сербохорватского языка // Вестник РГГУ. Серия: Литературоведение. Языкознание. Культурология. - 2021. - № 2. - С. 85-116.

66. Каплунова М. Я. Международный круглый стол «Перспективы и вызовы языковой политики и языковой ситуации в Крыму» // Социолингвистика. - 2020. - № 1 (1). - С. 154-163.

67. Хилханова Э. В., Каплунова М.Я. Первое заседание дискуссионноаналитического клуба по языковой политике (Москва, Институт языкознания РАН, 17 марта 2020 г.). [Электронный ресурс] // Социолингвистика. - 2020. № 1. - C.124-132.

68. Иванов В. В. Второе заседание дискуссионно-аналитического клуба по языковой политике (Москва, Институт языкознания РАН, 6 октября 2020 г.). [Электронный ресурс] // Социолингвистика. - 2020. - № 2(2). - С. 168-171.

69. Селиверстова О. А. К вопросу о дефиниционных различиях понятий «языковая политика» и «языковое планирование» в отечественной и зарубежной лингвистике // Известия Волгоградского государственного педагогического университета. - 2014. - С. 8-12.

70. Скачкова И. И. Языковая политика и языковое планирование: определение понятий // Политическая лингвистика. - 2015. - № 1 (51). C.126-131.

71. Багана Р. Ж. Языковое планирование в современной лингвистике // Наука, образование и культура. - 2016. - С. 36-38.

72. Алпатов В. М. Языковая политика и родной язык [Электронный ресурс] // Социолингвистика. - 2020. - № 3(3). - С. 114-124.

73. Гришаева Е. Б. Современные парадигмы языковой политики в условиях полиэтнического и мультикультурного пространства // Вестник Московского университета. Серия 21. Управление (государство и общество). 2015. - № 4. - C.143-159. 
74. Морозова Н. В. Два измерения соотношения языка и власти // Вестник РГГУ. Серия: Политология. История. Международные отношения. 2015. - C. 114-122.

75. Кобенко Ю. В. Языковая политика и языковое планирование в призме регуляции корпуса и статуса титульного языка // Вестник Ленинградского государственного университета им. А. С. Пушкина. - 2010. Т.1. - Вып. 1. - С. 193-198.

76. Едличко А. И. Русский язык в России и в мире: некоторые аспекты языковой политики // Филологические науки. Вопросы теории и практики. 2018. - № 11 (89). - Ч.1. - С.99-107.

77. Биткеева А. Н., Вингендер М., Михальченко В. Ю. Прогнозирование и языковое многообразие в Российской Федерации: социолингвистический аспект // Вестник Волгоградского гос. ун-та. Серия 2: Языкознание. - 2019. - Т. 18. - № 3. - С. 6-23.

78. Биткеева А. Н., Вингендер М. Сценарии в языковой политике России: вопросы концепции и методологии [Электронный ресурс] // Социолингвистика. - 2020. - № 1. - С. 34-53.

79. Замятин Константин. Принятие языковой политики в республиках постсоветской России: акторы, дебаты, решения [Электронный ресурс]. Социолингвистика. - 2020. - № 2(2). - С.30-66.

80. Рыжков А. М., Петрова Э. О., Влахов А. В. Языковая политика и локальные идентичности в российско-скандинавском приграничье [Электронный ресурс] // Социолингвистика. - 2021. - № 2 (6). - С. 128-144.

81. Паршаков А. С. Украинская языковая политика: Между унитаризмом и федерализмом // Социс. - М., 2014. - № 2 (358). - С. 51-54.

82. Горностаева А. А. Языковая политика в сфере образования на территориях проживания коренных малочисленных народов Севера Красноярского края [Электронный ресурс] // Социолингвистика. - 2021. № 2(6). - C. 164-186.

83. Горячева М. А. Украинский язык в школьном обучении в Российской Федерации: динамика и тенденции функционирования в контексте языкового прогнозирования [Электронный ресурс]. Социолингвистика. - 2020. - № 2 (2). - С. 92-106.

84. Едличко А. И. Коммерциализация языка в аспекте языковой политики государства // Вестник московского университета. Серия 19. Лингвистика и межкультурная коммуникация. - 2017. - № 4. - С.118-127. 
85. Кадочников Д. В. Цели и задачи языковой политики и проблемы социально-экономического развития России // Terra economicus. - 2019. - № 17 (1). - C. 96-111.

86. Мандрикова Г. М., Коротич С. А. Правовой и функциональный статус языков Российской Федерации // Экология языка и коммуникативная практика. - 2017. - № 3. - С 13-29.

87. Шевалье Дж. Ф. Сохранение исчезающих языков: опыт и его применение // Мир науки, культуры, образования. - 2011. - № 3 (28). - С. 87-88.

88. Рязанцев С. В. О языковой интеграции мигрантов как новом ориентире миграционной политики России // Социс. - М, 2014. - № 9 (365). C. 30-38.

89. Карасик В. И. Коммуникативная тональность // Актуальные проблемы филологии и педагогической лингвистики. - 2008. - № 10. C. 99-109.

90. Квеско Р. Б., Ванина И. Л., Квеско С. Б., Чубик А. П., Бухтояров А. П., Емельянова Н. Е. Социолингвистическая коммуникация как элемент социальных отношений // Известия Томского политехнического университета. Инжиниринг георесурсов. - 2007. - Т. 311. - № 7. - С. 51-67.

91. Марцинковская Т. Д., Власова Т. В. Потребность в языке в поле психологии личности и социолингвистики // Вестник Санкт-Петербургского унта. Психология. Серия 16. - 2013. - Вып.3. - С. 4-14.

92. Найман Е. А. Теория речевых актов в критическом зеркале лингвистической антропологии и социолингвистики // Язык и культура. -2015. - C. 53-62.

93. Леонтович О. А. «Всевидящее око» города через призму социолингвистики // Acta Linguistica Petropolitana. Труды института лингвистических исследований. 2018. С. 199-212.

94. Верхолетова Е. Ю. Теоретические основания структурнодинамического подхода к речи // Вестник Пермского университета: российская и зарубежная филология. - Пермь, 2010. - Вып. 4 (10). - С. 34-39.

95. Живлакова А. Е. Теоретические подходы к социолингвистическому анализу социально-политической дифференциации языка // Вестник Саратовского государственного технического университета. - 2010. - № 1 (44). - C. 275-279.

96. Солнышкина М. И., Зиганшина Ч. Р. Гараева Л. М. Социолектология: современное состояние и проблемы // Вестник 
Волгоградского гос. ун-та. Серия 2. Языкознание. - 2014. - № 4 (23). C.125-134.

97. Коровушкин В. П. Основы контрастивной социолектологии: монография: в 2 ч. - Череповец: ЧГУ, 2005.

98. Коровушкин В. П. Категориально-понятийная система контрастивной социолектологии как автономной отрасли языкознания (на материале английского и русского языков) // Вестник Череповецкого гос. университета. Раздел 2. Лингвистика. - 2008. - С. 73-85.

99. Ерофеева Т. И., Ерофеева Е. В. Социальная диалектология в Пермском университете (краткий обзор, 1916-2016) // Вестник Пермского университета. Российская и зарубежная филология. - 2016. - Вып.3 (35). C.112-121.

100. Косова В. А., Сунь Мяо. Функциональная семантика универбов в русских социолектах // Филология и культура. - 2015. - № 3 (41). - С. 67-74.

101. Рюмин Р. В. Формирование русской социолектной лексикографии как самостоятельной отрасли языкознания и ее современное состояние // Вестник Иркутского гос. лингвистического ун-та. - 2010. - № 1 (9). C. 195-202.

102. Мокиенко В. М. Социолекты в зеркале лексикографии// Вопросы лексикографии. - 2013. - С.76-93.

103. Солнышкина М. И., Тагирова Л. И. Двуязычная социолектография: состояние и проблемы // Филология и культура. - 2013. - № 4 (34). - С. 125-132.

104. Ильина Е. Н. Диалектная языковая личность в фокусе лингвистических проблем // Вестник Череповецкого гос. ун-та. - 2015. - № 2. C. 75-79.

105. Черняева М. И. Языковая личность жительницы русского Севера и проблемы современной диалектологии // Вестник Череповецкого гос. ун-та. 2015. - № 3. - С. 94-96.

106. Сперанская А. Н. Индивидуальный речевой портрет жительницы Северного Приангарья // Экология языка и коммуникативная практика. - 2017. - № 4. - С. 97-115.

107. Ильина Е. Н. «Лингвистический код» региональной идентичности жителей Вологодского края в динамическом аспекте // Вестник Череповецкого гос. ун-та. - 2017. - № 6. - С. 85-91. 
108. Волкова Н. А., Ганичева С. А. Загуменнов А. В., Ильина Е. Н., Мельникова Н. Г. Народная речь Вологодского края: опят мужского речевого портрета: Монография. Вологда; Череповец: Череп. гос. ун-т. - 2017. - 232 с.

109. Волошина С. В., Шевчик А. В. Фрагмент речевого портрета жителя современного российского села // Экология языка и коммуникативная практика. - 2018. - № 3. - С. 20-32.

110. Полищук Д. С., Дарбанова Н. А. Фонетические и морфологические черты как фрагменты речевого портрета диалектоносителя // Вестник Бурятского гос. ун-та. Язык. Литература. Культура. - 2017. - Вып. 3. - С. 22-30.

111. Ганичева С. А. Воспоминания брата и сестры о деревенском детстве: лингвогендерологический аспект // Вестник Череповецкого гос. ун-та. - 2019. - № 5. - С. 67-78.

112. Иванищева О. Н. Социолингвистические подходы к исследованию приграничного северного региона // Известия Российского гос. педагогического ун-та им. А. И. Герцена. Языкознание. - 2008. - С. 114-121.

113. Драчева Ю. Н., Зубова Н. Н. Мультимедийный корпус «Жизненный круг» как основа изучения когнитивной составляющей диалектной языковой личности // Вестник Череповецкого гос. ун-та. - 2015. - № 6. - С. 58-61.

114. Бондаренко Е. Д. К дифференциации подъязыков с позиция наивной социолингвистики (на материале русских говоров) // Антропологический форум. - 2013. - № 18. - С. 373-380.

115. Егорова С. С. Судьба русского просторечия (по материалам исторических словарей) // Проблемы истории, филологии, культуры. - 2011. C.381-387.

116. Кудинова Т. А. Просторечие как лингвистический феномен: динамика понятия // Научная мысль Кавказа. - 2009. - № 4. - С. 135-138.

117. Неверов А. П. Просторечие и его функциональный аспект // Приволжский научный вестник. - 2014. - № 6 (34). - С. 109-111.

118. Титова Е. В. О стилистическом статусе просторечия в русском языке (лексикографический обзор) // Вестник Санкт-Петербургского университета. Язык и литература. - 2009. - Сер. 9. - Вып. 3. - С. 306-311.

119. Адамия 3. К. Просторечие как компонент в лексике кодифицированного языка и его отражение в толковых словарях // Проблемы истории, филологии, культуры. - 2014. - № 3 (45). - С. 250-252. 
120. Пирко В. В. Временная гетерогенность просторечия [Электронный pecypc] // Слово: фольклорно-диалектологический альманах. - 2009. Выпуск 7.

121. Холодкова М. В. Функционально-семантическая специфика просторечной лексики в современном русском языке // Вестник Московского государственного областного университета. Серия: Русская филология. - 2018. - № 5. - С. 130-138.

122. Фельде О. В. Русское профессиональное просторечие в свете теории LSP (language for special purposes) // Вестник Забайкальского гос. ун-та (ЧитГУ). - 2010. - № 9 (66). - С. 48-52.

123. Саляев В. А. Аспекты нормативно-стилистической характеристики в общих толковых словарях (на материале анализа пометы «просторечное») // Проблемы истории, филологии, культуры. 2011. № 3(33) С. 72-76.

124. Шпыг Ю. В. Разговорная и просторечная лексика русского языка XX - начала XXI века: проблемы лексикологической интерпретации // Научный вестник Воронежского гос. архитектурно-строительного ун-та. Серия: Лингвистика и межкультурная коммуникация. - 2007. - № 3 (3). - С. 14-18.

125. Холодкова М. В. Определение состава просторечной лексики // Вестник Тамбовского университета. Серия: Гуманитарные науки. - 2008. Выпуск 10 (66). - С. 49-52.

126. Валиева Л.Ф. Проблема разграничения разговорной и просторечной лексики в русском языке // Вестник Югорского государственного университета. - 2016. - Выпуск 1 (40). - С. 49-52.

127. Коровушкин В. П. Одноязычные словари русского лексического просторечия: учебно-методическое пособие. - Череповец: ЧГУ, 2004. - 55 с.

128. Козлова Р. П., Холодкова М. В. Общерусские просторечные признаки в живой речи жителей г. Тамбова // Филологическая регионалистика. - 2009. - № 1-2 (1-2). - С. 96-98.

129. Холодкова М. В. Фонетическая просторечность в разговорной речи жителей г. Тамбова // Вестник Тамбовского университета. Серия: Гуманитарные науки. - 2009. - Выпуск 7 (75). - С. 282-286.

130. Пирко В. В. К вопросу о системности лексики просторечия (на материале просторечия Приамурья) [Электронный ресурс] // Слово: фольклорно-диалектологический альманах. - 2009. - № 3. 
131. Юнаковская А. А. «Язык города»: основные компоненты и их функционирование (на материале г. Омска) // Гуманитарный вектор. Серия: Педагогика, психологи. - 2010. - № 3 (23). - С. 116-121.

132. Соломина Е. В. Об особенностях идиолексикона носителя городского просторечия // Вестник Томского гос. ун-та. - 2013. - № 374. C. 37-41.

133. Соломина Е. В. О стилевой дифференциации речи носителя городского просторечия // Сибирский филологический журнал. - 2016. - № 2. C. 134-143.

134. Крысин Л. П. Специальный термин в русском просторечии // Вестник РГГУ. Серия: Литературоведение. Языкознание. Культурология. 2013. - № 8 (109). - C.75-85.

135. Химик В. В. Диффузное варьирование слов, значений и формантов в русской разговорно-обиходной речи // Вестник Нижегородского университета им. Н.И. Лобачевского. - 2011. - № 6 (2). - С. 717-720.

136. Химик В. В. Русская разговорно-обиходная речь в лексикографическом представлении // Филологический класс. - 2014. - № 1 (35). - C.58-64.

137. Рюмин Р. В. Разговорная лексика в социолектной лексикографии // Вестник Ленинградского гос. ун-та им. А. С. Пушкина. - 2008. - С. 149-157.

138. Фельде О. В. Проблемы и перспективы лексикографического описания русского профессионального субстандарта // Вестник Челябинского гос. ун-та. - 2011. - № 33 (248). Филология. Искусствоведение. Вып. 60. C.209-212.

139. Химик В. В. Толковый словарь русской разговорно-обиходной речи. В 2 т. - СПб.: Златоуст, 2017. - Т.1. - 258 с.; Т.2. - 532 с.

140. Сафонова Ю. А. Предлагаемые обстоятельства обихода и его словесный репертуар // Политическая лингвистика. - 2017. - № 4 (64). C. 129-136.

141. Богданова-Бегларян Н. В., Блинова О. В., Мартыненко Г. Я., Шерстинова Т. Ю. Русский язык повседневного общения: некоторые количественные данные в зеркале социолингвистики // Коммуникативные исследования. - 2016. - № 3 (8). - С.81-92.

142. Богданова-Бегларян Н. В. Функционирование некоторых прагматем русской устной речи в коммуникации представителей разных социальных 
групп // Вестник Пермского университета. Российская и зарубежная филология. - 2016. - Вып. 2 (34). - С. 38-49.

143. Крысин Л. П. Специальный термин в русском просторечии // Вестник РГГУ. Серия: Литературоведение. Языкознание. Культурология. 2013. - № 8 (109). - С.75-85.

144. Толковый словарь русской разговорной речи. Вып. 1: А - И / Российская акад. наук, Ин-т русского языка им. В.В. Виноградова; под ред. Л. П. Крысина - М.: Языки славянской культуры, 2014. - 776 с.

145. Какорина Е.В. Политический, медийный, бытовой дискурсы точки соприкосновения, языковые рефлексы (на материале «Толкового словаря русской разговорной речи»). // Экология языка и коммуникативная практика. 2019. - № 2. - С. 42-56.

146. Горбунова И. В. Социолингвистический эксперимент в образовательном пространстве: к проблеме использования слов-паразитов в русской разговорной речи // Бизнес-образование в экономике знаний. - 2019. № 1. - С. 12-16.

147. Герд А. С. О лингвистическом подходе к понятию «жаргон»// Слово в словаре и дискурсе / А. Бирих, Т. Володина (ред.). - М., 2006. C. 201-208.

148. Калугина Е. Н. Понятийно-теоретический аспект исследования языкового субстандарта // Научный диалог. - 2013. - № 5 (17): Филология. C. 261-269.

149. Ретинская Т. И. О понятии «профессиональное арго» и задачах современной арготологии // Ученые записки Орловского государственного университета. Серия: Гуманитарные и социальные науки. - 2011. - № 1 (39). C. 206-211.

150. Саляев В. А. Лексикографирование русского сленга: проблемы и решения // Проблемы истории, филологии, культуры. - 2009. - № 2 (24). C. 522-526.

151. Попов Р. В. Некоторые проблемы описания профессиональных жаргонизмов в субстандартных словарях // Вестник Челябинского гос. ун-та. 2013. - № 31 (322). Филология. Искусствоведение. Вып. 84. - С. 63-66.

152. Попов Р. В. Вопросы лексикографической фиксации жаргонов // Проблемы истории, филологии, культуры. - 2014. - № 3 (45). - С.186-187.

153. Рюмин Р.В. Опыт лексикографирования студенческого жаргона // Культурная жизнь Юга России. - 2008. - № 2 (27). - С.123-124. 
154. Ретинская Т. И., Войнова Н.В. Об одной из констант алгоритма микросоциолингвистического исследования [Электронный ресурс]. Социолингвистика. - 2020. - № 4 (4). - С. 34-48.

155. Стрельчук В. Жаргонизмы в речи современной молодежи // Вестник МГУП имени Ивана Федорова. - 2014. - № 3. - С.90-96.

156. Вензель А. Е. Особенности функционирования жаргонной лексики в речи студентов // Наука, техника, образование. - 2015. - № 11 (17). C. 121-123.

157. Кропачева М. А. Особенности стилистической маркированности лексики молодежного жаргона // Международный научно-исследовательский журнал. - 2014. - № 1-2 (20). - С.110-111.

158. Акимова Т. И. Студенческий жаргон и словообразование. Явление лексической моды в студенческой среде // МГУП имени Ивана Федорова. 2011. - C.187-191.

159. Андросова О. Е. Связь основных социально-демографических факторов со спецификой употребления жаргона учащейся молодежью // Студенческий жаргон как объект лингвосоциопсихологического исследования / О. Е. Андросова. - Пенза, 2006.

160. Надеина Т. М., Лукашевич М. С. Англицизмы в молодежном сленге: факторы распространенности и освоенности // Актуальные проблемы культуры речи: материалы Всероссийской научно-практической конференции (г. Москва, МГОУ, 13 мая 2020) / отв. ред. И.С. Папуша. - М.: Принтика, 2020. - C.18-23.

161. Гришкова В. И. Проявление гендерного фактора в молодежном жаргоне // Вестник РУДН: серия «Вопросы образования: языки и специальность». - 2006. - № 1 (3). - С. 53-56.

162. Елистратов А. А. К вопросу о заимствованиях в молодежном жаргоне: контрастивный анализ на материале английского и русского языка // Вестник Иркутского гос. лингвистического ун-та. - 2014. - С. 208-213.

163. Елистратов А. А. Контрастивный анализ географической вариативности английского и русского молодежных жаргонов // Известия Российского гос. педагогического ун-та им. А. И. Герцена. - 2015. - С. 52-61.

164. Копоть Л. В. Универбация как явление словообразования с точки зрения социолингвистики // Вестник Адыгейского гос. ун-та. Сер.2: Филология и искусствоведение. - 2007. - № 2. - С. 47-51. 
165. Сокорева Т. В. Ритм изменяется с возрастом (акустический анализ спонтанной речи 102 жителей США) // Вестник Московского государственного лингвистического университета. Гуманитарные науки. - 2015. - Выпуск 1 (712). - C.214-230.

166. Сокорева Т. В., Шевченко Т. И. Взаимодействие факторов региональной принадлежности и возраста в ритмотемпоральных характеристиках речи жителей США // Вестник Московского государственного лингвистического университета. Гуманитарные науки. - 2016. - Выпуск 1 (740). - C. $155-164$.

167. Лю Даян. Идиоматика в повседневной русской речи носителей языка: гендерный и возрастной аспекты // Мир русского слова. - 2019. - № 1. C. 14-20.

168. Бабушкина Е. А. Диапазон речи говорящего как социальный маркер // Вестник Бурятского государственного университета. Язык. Литература. Культура. - 2009. - № 11. - С. 5-7.

169. Бабушкина Е. А. Темп речи как социальный маркер // Вестник Бурятского государственного университета. Язык. Литература. Культура. 2010. - № 11. - С.13-17.

170. Бабушкина Е. А., Александров А. С. Роль интонационных характеристик речи в определении социально-этнической принадлежности говорящего // Вестник Бурятского государственного университета. Язык. Литература. Культура. - 2011. - № 11. - С. 13-18.

171. Муманова Т. В. Интонационное оформление речи как маркер социальной принадлежности говорящего // Вестник Бурятского гос. ун-та. 2014. - № 11. - C.24-29.

172. Шевченко Т. И. Социокультурные основания вариативности английского ударения и ритма: вопросы методологии // Вестник Московского государственного лингвистического университета. Гуманитарные науки. 2018. - Вып.3. - С. 100-110.

173. Демина М. А., Карташевская Ю.В. Гендерно-маркированные модели просодической согласованности коммуникантов в small talk // Вестник Московского государственного лингвистического университета. Гуманитарные науки. - 2017. - Выпуск 5 (776). - С. 9-31.

174. Бабушкина Е. А. Просодия дикторской речи // Вестник Бурятского государственного университета. Язык. Литература. Культура. - 2012. - № 11. C.11-15. 
175. Корнелаева Е. В. Просодические маркеры профессиональной принадлежности говорящего // European science review. - 2014. - № 5-6. C.137-139.

176. Карасик В. И. Выражение статусных отношений средствами русского языка // Русский язык в современном обществе: (Функциональные и статусные характеристики). Сб. обзоров. Сер. "Теория и история языкознания" Отд. языкознания; Отв.ред.: Опарина Е. О., Казак Е. А. - М., 2005. - С. 30-50.

177. Чудинов А. П., Нахимова Е. А., Никифорова М. В. Российская лингвополитическая персонология: исследование дискурса политических лидеров // Вестник Российского университета дружбы народов. Серия: Теория языка. Семиотика. Семантика. - 2018. - Т. 9. - № 1. - С. 14-31.

178. Сейранян М. Ю. Просодическая реализация открытого и скрытого конфликта в политическом дискурсе // Rhema. Рема. - 2019. - № 1. - С. 79-92.

179. Васильев А. Д., Васильева С. П. Элементы социальной маркированности в российском официозном дискурсе // Вестник Красноярского государственного педагогического университета им. В. П. Астафьева. Филология. Языкознание. - 2019. - № 3. - С.185-195.

180. Кондратьева О. Н. Политика в зеркале языка и культуры: уральская школа политической лингвистики // Язык и культура. - 2018. - № 41. C. 153-168.

181. Гаврилова М. В. Президентский дискурс // Дискурс-Пи. Энциклопедия «Дискурсология». - 2013. - С. 114.

182. Гаврилова М. В. Лингвистический анализ выступлений главы государства: тематика, направления и методы исследования // Политическая наука. - 2017. - № 2. - С.55-72.

183. Цветкова Е .Б. Языковые маркеры женского политического дискурса в аспекте прагмалингвистики // Актуальные проблемы филологии и методики преподавания иностранных языков. - 2013. - № 7. - С. 66-71.

184. Иванцова Е. В. Изучение языковой личности в Томской лингвистической школе // Вестник Томского гос. ун-та. - 2006. - № 291. C. 5-11.

185. Гордеева М. Н. Речевой портрет и способы его описания // Лингвостилистические и лингводидактические проблемы коммуникации. - М., 2008. - № 6. 
186. Михалевич О. В. Проблема изучения языковой личности в лингвистике: исторический аспект // Вестник КРАУНЦ. Гуманитарные науки. 2011. - № 1 (17). - С. 145-151.

187. Карасик В.И. Языковая личность: аспекты изучения // Язык vs. социум: XXI век. Коллективная монография. / гл. ред. Н.В. Юдина. - Владимир, 2020. - C.178-182.

188. Никифорова М. В., Чудинов А. П. Лингвополитическая персонология: методологические основы и методики анализа // Актуальные проблемы филологии и педагогической лингвистики. - 2017. - № 1. - С. 22-29.

189. Бабушкина Е. А. Речевой потрет личности: фонетические характеристики // Вестник Бурятского государственного университета. Язык. Литература. Культура. - 2012. - № 11. - С.7-11.

190. Шапошникова И. В. Динамические модели в социолингвистике и социокоммуникативные установки русской языковой личности в постсоветский период // Вестник Волгоградского гос. ун-та. Серия 2: Языкознание. - 2019. Т. 18. - № 3. - С.24-38.

191. Гаврилова М. В. Некоторые черты речевого портрета первого президента России Б.Н. Ельцина // Политическая лингвистика. - 2012. - № 4 (42). - C. 17-22.

192. Гаврилова М. В. Дискурсивный портрет В. В. Путина // ДискурсПи. Энциклопедия «Дискурсология». - 2013. - С. 114-115.

193. Родина Н. А. Фрагмент описания личности российского военнослужащего в свете социолингвистики (на материале бытования индивидуальных маркеров) // Социально-экономические явления и процессы. 2017. - T.12. - № 1. - С. 150-154.

194. Карасик В. И. Сетевая языковая личность // Вестник Московского государственного лингвистического университета. Гуманитарные науки. 2021. - № 6 (848). - C. 33-45.

195. Черняк В. Д. Речевой портрет носителя просторечия // Современный русский язык: социальная и функциональная дифференциация / Л. П. Крысин. - М.: Языки славянской культуры, 2003. - С. 497-513.

(C) Т.М. Надеина, 2022 